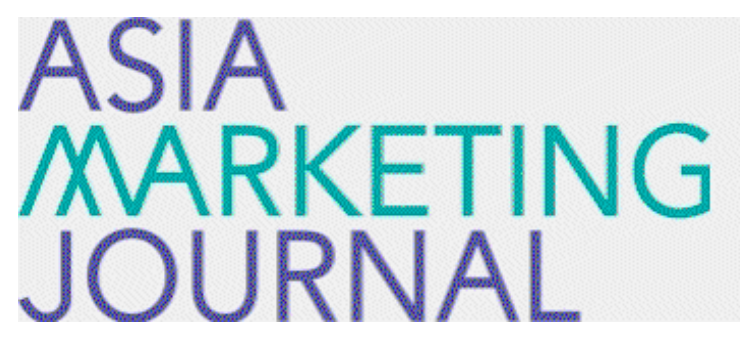

ASIA MARKETING JOURNAL

Volume 4 | Issue 1

Article 3

3-1-2002

\title{
바람직한 상호변경에 관한 탐색적 연구
}

Dae Ryun Chang

Gang Ok Jung

Dong Ryun Chang

Follow this and additional works at: https://amj.kma.re.kr/journal

Part of the Marketing Commons

\section{Recommended Citation}

Chang, Dae Ryun; Jung, Gang Ok; and Chang, Dong Ryun (2002) "바람직한 상호변경에 관한 탐색적 연구," Asia Marketing Journal: Vol. 4 : Iss. 1 , Article 3.

Available at: https://doi.org/10.53728/2765-6500.1080

This Article is brought to you for free and open access by Asia Marketing Journal. It has been accepted for inclusion in Asia Marketing Journal by an authorized editor of Asia Marketing Journal. 


\title{
바랍직한 상호변경에 관한 탐색적 연구* \\ -한국 기업의 경우
}

\section{An Exploratory Study on Desirable Changes for Corporate Names -The Case of Korean Companies}

\author{
장대련 (연세대학교 경영학과 교수) \\ drchangyonsei.ac. kr
}

정강옥(연세대학교 경영연구소 선임연구원)

gojungebase.yonse i.ac.kr

장동련 (홍익대학교 시각디자인과 조교수)

denaechollian.net

\begin{abstract}
상호는 기업의 핵심 자산이며 브랜드의 가장 중요한 구성 요소이다. 그러므로 상호변 경은 기업 가치와 기업 이해관계자의 반웅에 영향을 미칠 수 있다. 본 연구는 마케팅 측면에서 우리나라 기업들의 상호변경에 대하여 다루었다. 연구 방법으로 사례 및 이의 내용 분석을 실시하였다.

연구 결과, 변경된 상호는 짫아진 경우가 많았으며, 상호의 제품 묘사 정도는 감소한 것으로 나타났다. 상호의 지역 표현은 제거되거나 감소되었으며, 절대적으로 필요하지 않는 단어는 상호에서 제거되는 것으로 나타났다. 약자 상호와 신조어 상호의 사용은 중가한 것으로 밝혀졌다. 우리나라 기업의 상호변경 톡성으로 모기업 상호로 상호변경 이 이루어진 경우가 많았으며 한자어와 영어로 된 상호가 다수를 차지하고 있었다. 그 리고 이러한 현상의 대부분은 서비스업보다 제조업의 상호변경에서 더 높게 나타났다.

후반부에 바람직한 상호의 특성과 역할을 브랜드 관련 문헌들올 토대로 하여 제시하 고 이률 우리나라 기업의 상호변경 사례 분석에 대비하여 논하였다. 마지막으로 본 연 구의 마케팅 및 브랜드에서의 시사점과 향후 연구 방향율 제시하였다.
\end{abstract}

* 논문접수 : 02.06 게재학정 : 02.07

저자들은 심사위원들의 건설적인 조언에 감사드립니다. 본 연구는 연새대하교 경영연구소 $\mathrm{Brand} \&$ Business 마케팅연구센터의 2002 년도 지원에 의해 이루어졌다. 


\section{1. 서 론}

세계적인 브랜드 컨설팅 혀사인 Interbrand 는 매년 세계에서 가장 가치있는 브랜드들의 순위를 발표한다. 2000 년, 2001 년에 발표된 브랜드 자료에 따르면 1 위부터 10 위까지의 브 랜드 모두가 상호(corporate name 또는 trade name) 브랜드임을 알 수 있다(Interbrand 2000, 2001). 2001 년에 Businessweek 에서 발표한 자료에서도 세계 100 대 브랜드의 대부분 이 상호 브랜드이다(Businessweek 2001). 이들 브랜드 순위에 삼성이 우리나라 브랜드로서 처음으로 50 위퀀에 진입했는데 삼성이라는 브랜드 역시 상호 브랜드이다. 브랜드는 브랬드 명, 로고, 캐릭터, 슬로건, 징글, 패키징 등으로 구성되는데 이 중에서 가장 중요한 것은 브랜드명이다(Aaker 1991, Keller 1998), 상호는 기업 브랜드명으로서 기업 브랜드 자산의 핵심이다. 기업은 상호률 통해 기업 아이덴티티를 표현하며 소비자는 상호를 통하여 기업을 인지하고 지각한다.

기업의 브랜드 구조는 브랜드명 명명 체계에 의해 구분된다(Fombrun 1996, Aaker and Joachimsthaler 2000). 기업의 브랜드 구조는 기업이 사용하는 브랜드의 개수와 이들간의 연결 관계에 따라 단일형, 제품 계열형, 개별 제품형으로 나눌 수 있다(Schmitt and Simonson 1997). 기업들은 제품, 시장, 소비자 톡성에 따라 다른 브랜드 구조 전략을 사용 하지만 상호는 기업의 브랜드 전략과 구조에서 기본 축 역할을 한다.

브랜드가 기업의 지속적 경쟁 우위 창출 수단으로 그 비중이 증대함에 따라 상호의 중요 성도 중가하고 있다(Aaker 1991). 이에 기업들은 상호라는 브랬드의 자산 가치를 중가시키 기 위해 노력하고 있다(Keller 1998). 자동차의 경우에 우리나라 소비자둘은 모델명인 개별 브랜드명에 따라 제품 차이를 검토하지만 차종 선택에서 최종적으로 고려하는 것은 상호이 다(유창조, 김영찬 2001), 이는 자동차와 같은 고관여 제품의 구매에서 중요하게 작용하는 브랜드는 개별 제품 브랜드명이 아니라 상호라는 기업 브랜드명이라는 것을 시사해 주는 것 이다. 특히 서비스 산업에서 소비자가 중요하게 고려하는 것은 서비스률 제공하는 기업의 상호인데(Krishnan and Hartline 2001), 신뢰를 주는 상호는 소비자 평가에 긍정적인 영향 을 미친다(Keller 1998). 기업이 사업을 시작하고 상호를 보호하기 위해서는 상호 둥기를 해야 한다. 기업은 상호가 없으면 제도적으로 성킵할 수 없다(조혁근 2002). 그러므로 기업 은 가능하면 설립 이전에 사명(corporate mission), 목적, 전략, 가치, 문화, 사업 및 제품 유형, 소비자, 제공하는 고객 편익에 적합하며 이률 구체화하고 생생하게 표현할 수 있는 적절한 상호를 개발하는 것이 바람직하다(Collins and Porras 1996). 왜냐하면 적절하지 않 은 상호는 기업을 궁지에 몰아 넣는 요인이 되기도 하며 경쟁 열위의 원천으로 작용할 수 있기 때문이다. 반면에 좋은 상호는 기업에게 지속적인 경쟁 우위의 원천을 제공해 줄 수 있으며 마케팅 효율성을 높여준다. 이에 어떤 마케팅 전문가들은 상호와 같은 브랜드명을 만드는 것이 가장 중요한 마케팅 의사결정이다라는 주장을 하기도 하였다(Ries and Trout 1981). 그런데 기업에서는 이전부터 사용해 오던 상호가 적절하지 않아 상호를 변경해야 하 는 경우가 발생하기도 하며 이에 따른 상호변경이 증가하고 있다. 상호를 변경하려면 변경 상호라는 새로운 브랜드명이 필요하고 이에 적절한 상호를 개발하는 것도 브랜드명 결정의 일종이다. 이에 우리나라 기업들의 상호변경 내용과 톡성을 밝히고 이를 규명해 볼 펼요가 있다고 판단된다. 예냐하면 상호 브랜드가 점점 더 중요해지고 있고 우리나라 기업들의 상 호변경이 지속적으로 중가해 왔기 때문이다. 이에 따라 본 뎐구는 우리나라 기업의 상호변 
경을 변경상호의 특성, 유형, 내용, 변화 추이률 파악하기 위해 이루어졌다. 본 연구에서는 상호변경을 브랜드명 측면에서 파악하여 상호의 길이, 지역성, 단어 가감, 약자화, 신조어 화에 대하여 분석해 보고 우리나라 기업의 상호변경 특성으로 변경 상호의 모기업 상호와의 통합과 분리, 변경상호 언어, 연대별 변경상호 특징에 대하여 살펴 보았다. 그리고 결론 부 분에서 바람직한 상호변경 및 상호 브랜드에 대해 상호변경 분석 결과와 사례에 기반하여 논의하였다.

\section{2. 선행연구 및 연구 방법}

기업의 상호변경이 일반화된 시기는 1980 년대 이후이다(Keller 1998). 미국에서 1980 년 대 이후 기업들간의 인수합병이 급중하자 이에 따른 상호변경도 급중하였다. 또한 1990 년 대 이후 기업들이 브랜드의 중요성을 인지하면서부터 대표적인 브랬드인 상호가 기업 전략 이나 사업에 적절하지 않거나 상호에 대한 소비자 반웅이 미진한 경우에 상호변경이 많이 이루어졌다. 우리나라에서 상호변경이 일반화된 시기는 1990 년 이후이다. 1990 년 이후로 국내 중권시장이 할성화되고, 1997 년의 IMF 사태 이후 기업의 경쟁력 강화 차원에서 구조조 정에 따른 기업들간의 인수합병이 급증하자 상호변경도 중가하였다. 그리고 1999 년 이후 코스닥(Korea Securities Dealers Automated Quotation, 이하 KOSDAQ) 시장이 활성화되면서 부터 벤처 기업들의 상호변경 또한 증가하였다. 한편 우리나라 기업들도 1990 년대 중반 이 후 지속적 경쟁 우위 창출 수단으로 상호 브랜드의 중요성을 인지하고 이의 체계적인 관리 를 시도해 오고 있다. 상호 브랜드의 체계적인 관리의 한 방편으로 CIP(Corporate Identity Program, 이하 CIP)가 많이 이루어졌는데 이에 따라 다수의 상호가 변경되었다(이태희, 박 찬수 2000). 또한 1990 년대 후반 이후에 인터넷, 전자상거래로 대표되는 디지털 경제가 일 반화되자 전통적인 이미지가 강한 기업들의 상당수가 벤처 기업들에 대응하고 첨단 기업 이 미지를 창출하기 위해 상호변경을 단행하였다.

\section{1 상호변경의 동기 및 비용}

기업의 상호변경을 유발하는 원인은 시장, 소비자, 경쟁사, 전략, 사업 측면에서 다양하 계 발생한다. 기업이 상호를 변경하는 동기로는 인수합병, 분사, 시장 확장, 사업의 변경, 사업의 확장 또는 축소, 사업 우선 순위의 변화, 시대에 뒤떨어지거나 부정적인 이미지 개 선, 소비자 기호의 변화, 기업 소유권의 변화, 정부의 규제 및 규제 완화, 경쟁 대웅 둥이 있다(Aaker 1996, Schmitt and Simonson 1997, Koku 1997). 이 중에서 마케팅 측면에서의 상호변경의 주요 원인은 소비자 기호 변화에 대한 대처와 비우호적이거나 구시대적인 이미 지의 개선과 차별화이다. 미국에서는 1980 년대 이후부터 제품의 기능이나 성능이 유사해져 이에 의한 차별화와 소비자 선호 창출이 어려워졌다. 그리고 제품 품질 차이가 소비자가 지 각하는 수준에서 거의 없게 되자 품질 차별화도 한계에 부딪히게 되었다. 이러한 상황에서 차별화의 새로운 원천으로 등장한 것이 브랜드 이미지에 의한 차별화이다. 차별적인 브랜드 이미지는 독특하고 강력하며 호의적인 브랜드 아이덴티티(brand identity)의 창출을 통해서 
가능하다(Keller 1993). 이러한 브랜드 아이덴티티를 창출하기 위해 브랜드 아이덴티티의 기본 토대가 되는 브랜드명의 전략적 활용이 중가하게 된 것이다(Aaker 1991, 1996). 이에 기업이 추구하는 아이덴티티에 기존 상호가 적절하지 않거나 상호 이미지가 긍정적이지 않 은 경우에 상호변경이 상당수 이루어졌다.

상호변경으로 발생하는 비용은 직접 비용과 간접 비용으로 구분된다(Kohli and Hemnes 1995). 직접 비용은 기존 상호를 변경하거나 새로운 상호를 개발하고 디자인하는데 소요되 는 비용으로 이는 상호 개발 업무를 담당하는 부서의 운영비와 브랜딩 전문회사, 디자인 회 사, 광고대행사 등에 지불하는 수수료 등으로 발생하는 비용이다. 직접 비용의 규모는 상호 변경의 범위와 내용, 대행 기업의 전문성에 따라 천차만별이다. 수수료는 수천만원에서 수 억원에 이르며(송영균 1991), 상호변경을 외국의 브랜딩 전문회사에 의뢰하여 전세계적으로 통용될 수 있는 상호를 개발하는 경우에는 그 비용이 수십억원 대에 이르기도 한다. 하지만 상호변경에 의해 발생하는 비용의 대부분은 간접 비용이다(Koku 1997). 간접 비용은 주로 상호변경 고지 광고에 지출되는 비용, 서식 및 사무용품, 유니폼, 패키깅, 사인 체계 (signage system) 등의 변경 비용에 의해 발생한다. 외국의 경우에 Esso 가 Exxon 으로 상호 를 변경하면서 약 2 억 달러의 비용이 발생헸는테 이 비용의 대부분이 간접 비용이었다 (Kohli and Hemnes 1995). American Bell 이 AT\&T 로 변경하는데 약 3 천만 달러의 비용이 발생하였고(송영균 1991), UAL 이 Allegis 로 변경하는데 7 백만 달러의 비용이 소요되었는 데 이는 변경된 상호를 소비자에게 알리는데 든 비용올 제외한 것이다(Kohli and Hemnes 1995). 우리나라의 경우에는 2000 년 5 월에 쌍용정유가 S-0il 로 상호를 변경하면서 150 억 원 정도률 비용으로 지출한 것으로 업계 관계자들은 추정하고 있는데 이 비용의 대부분이 광고비와 주유소 사인 체계 변경비로 사용되었다.

\section{2 상호변경의 효과에 관한 연구}

상호변경의 효과에 관한 연구는 재무 측면의 연구와 마케팅 측면에서 이루어진 연구로 나 눌 수 있다.

재무 측면에서 이루어진 연구는 상호변경이 기업 가치에 미치는 영향에 관한 연구이다. Horsky and Swyngedouw(1987)는 미국의 상장기업 중에서 1981 년부터 1985 년 사이에 상호변 경을 Dow Jones News Services 에 발표한 기업 58 개를 대상으로 하여 상호변경이 주가에 미 치는 영향을 사건연구(event study)로 분석하였다. 연구 결과, 상호변경 기업의 평균 초과 수익률이 통계적으로 유의적인 것으로 나타나 상호변경이 기업의 가치를 상승시키는 것으로 밝혀졌다. 상호변경을 산업별로 분석했을 때 소비재 기업보다 산업재를 생산하는 기업에서, 그리고 금용관련 기업보다 비금융관련 기업에서 상호변경 효과가 높게 나타난다는 사실을 이들은 밝혀냈다. Koku(1997)는 상호변경을 신호 이론(signaling theory)율 이용하여 연구 하였다. Koku 는 미국 서비스 산업의 상장 기업들 중에 1980 년에서 1990 년 사이에 상호를 변경한 기업 28 개를 대상으로 하여 상호변경 전후의 주가수익비율(price per earning ratio, P/E ratio)을 비교 분석하였다. 연구 결과, 상호변경 이후의 주가수익비율이 변경 이전 보다 높게 나타났으며 상호변경 발표 후에 다른 경영 정보를 공시했올 경우에는 이러 한 효과가 더욱 크게 나타났다. 이는 서비스 산업에서 상호변경은 효과적인 마케팅 방법이 며 상호변경과 함께 추가적인 경영 정보를 공시하면 이것이 서비스 기업의 중요한 요소인 신뢰성올 강화시켜 주는 신호로 작용하여 그 효과가 더욱 크게 나타난다는 것을 의미하는 
것이다.

우리나라에서 상호변경이 기업 가치에 미치는 영향에 대한 연구로는 송영균의 연구(1991) 와 이태희, 박찬수의 연구(2000)가 있다. 송영균(1991)은 상호변경이 주가에 미치는 영향을 상호변경 유형, 소속 시장에 따라 다르게 나타난다는 것을 1980 년부터 1990 년까지 상호를 변경한 74 개 기업을 표본으로 한 사건연구를 퉁해 밝혀냈다. 연구 결과, 부분적인 상호변 경은 주가에 크게 영향을 미치지 못하지만, 기존 상호와 전혀 다른 상호로 변경하는 경우에 는 높은 초과 수읙률이 발생하며 주가에 유의적인 영향을 미친다는 것이 밝혀졌다. 그리고 상호변경 기업의 소속 시장이 1 부인 경우보다 2 부인 경우에 그 효과는 더 크게 나타나는 것으로 밝혀졌다. 또한 상호변경 사유가 인수합병에 의한 경우에는 주가에 큰 영향을 미치 지 않지만, 모기업의 상호나 주력 제품 브랜드명으로 상호를 변경한 경우에는 높은 초과 수 익률이 발생하는 것으로 나타났다. 이태희, 박찬수(2000)는 1992 년부터 1996 년 사이에 상 호변경으로 CIP 를 실시한 기업 31 개를 대상으로 사건연구를 실시하여 상호변경과 주가변동 과의 관계를 연구하였다. 연구 결과, CIP 에 의한 상호변경은 주가에 긍정적인 영향을 미치 지 않는 것으로 나타났다. 하지만 금융관련 기업보다 비금융관련 기업의 상호변경이, 산업 재 기업보다 소비재률 제조하는 기업의 상호변경이 주가에 긍정적인 영향울 미친다는 것을 밝혀냈다.

이상으로 국내외에서 이루어진 상호변경이 주가에 미치는 영향에 대한 연구들의 결과를 검토해 보면 그 결과가 상반되게 나타나고 있다는 것을 알 수 있다(Horsky and Swyngedouw 1987, 이태희, 박찬수 2000), 연구별로 다른 결과가 나온 것은 시장, 환경 특성, 표본 선정 및 이의 분류 방법, 분석 방법, 표본수, 기간, 독립 및 종속 변수 차이 등에 기인하는 것으 로 사려된다. 그런데 이들 연구는 상호변경이라는 사건이 기업 가치에 미치는 영향만을 다 루어서 상호변경에 관련된 상호의 자체 톡성이 소비자 및 시장 반응에 미치는 영향을 충분 히 고려하지 않았다는 한계가 있다. 마케팅에서 상호 또는 제품의 이름인 브랜드명은 해당 기업의 성공에 절대적인 요소는 아니지만 필수적인 요소이다(Keller 1998). 잘못된 브랜드 명은 소비자의 부정적인 반응을 유발하여 해당 기업이나 제품올 위험한 지경에 이르게 할 수 있고(Kotler 1994), 궁극적으로는 주가에 부정적인 영향을 미치는 요인으로 작용하기도 한다(Kogu 1997). 변경된 상호라는 브랜드명에 대한 소비자 반웅에 영향을 미칠 수 있는 요 소로는 상호 자체의 언어적, 의미적, 음성적, 형태적 특성과 기업 이해관계자의 톡징 등이 있다. 그런데 기존의 상호변경 연구들에서는 상호의 이런 자체적 특성에 대한 충분한 고려 없이 연구가 이루어졌다는 것도 상반된 연구 결과가 나온 원인 중에 하나라고 할 수 있다.

마케팅에서 이루어진 상호변경 연구는 상호 자체의 특성에 대한 연구이다. 이는 상호변경 전후의 상호라는 브랜드명의 특성에 대한 연구로서 Kohli and Hemnes 의 연구(1995)가 이의 대표적인 연구이다. 이들은 미국 증권거래소에 등록되어 있는 기업 중에서 1960 년부터 1991 사이에 상호변경을 한 기업들의 상호 866 개를 특성별로 나누어서 그 빈도를 분석하였 다. 연구 결과, 상호 길이가 길어진 경우보다는 짦아진 경우가 많았으며, 제품 묘사를 보다 구체화한 경우보다는 제품 묘사를 제거하거나 덜 구체적으로 한 경우가 많았다. 그리고 상 호에 지역적 표현을 구체화한 경우보다 이를 제거하거나 덜 구체적으로 한 경우가 많았으며, 절대적으로 필요하지 않은 단어롤 상호에 추가하는 경우보다 제거하는 경우가 많은 것으로 나타났다. 다음으로 약자 상호를 확장한 경우보다 기존 상호률 약자화한 한 경우가 많았으 며, 신조어를 상호에서 탈락시킨 경우보다 기존 상호를 신조어로 변경한 경우가 많은 것으 로 나타났다. 
하지만 이 연구 외에 마케팅 측면에서 이루어진 상호변경에 대한 연구는 거의 없는 실정 이다. 그리고 브랜드명 연구의 대부분은 단편적인 사례 연구로서 이는 연구자가 주장하는 바람직한 브랜드명 튝성에 부합하는 브랜드명을 실례로 제시하는 방식의 연구이다 (Robertson 1989, Aaker 1991, 1996). 한편 다른 일련의 연구로서 바람직한 브랜드명에 대 한 실중 연구의 상당수는 연구자가 제한적인 제품을 대상으로 하여 실헙 변수에 맞는 가상 의 브랜드명을 개발하여 이에 따른 소비자 반용을 연구한 것이다(LeClerc, Schmitt, and Dube 1994, Keller, Heckler, and Houston 1998, Schmitt and Zhang 2001). 그러므로 이들 연구는 연구 결과의 외적 타당성에 한계가 있으며 연구가 주로 영어로 이루어져 언어가 다 른 우리나라에 연구 결과를 적용하는 데에는 문제가 있을 수 있다. 이에 본 연구에서는 우 리나라 기업들의 상호변경 톡성울 파악하기 위해 상호변겅 사례룰 Kohli and Hemnes 의 연 구(1995)를 토대로 하여 그 내용과 빈도를 분석하고 브랜드명에 관련된 이론 및 연구들을 기반으로 해서 우리나라에 맞는 바람직한 상호변경 및 상호 브랜드 방안에 대하여 제시하였 다.

\section{3 연구 방법}

본 연구의 연구 방법은 사례 연구이다. 사례 연구의 주요 내용은 본 연구에서 규명하고자 하는 우리나라 기업 중에 상호변경울 한 기업의 변경 이전과 이후의 상호 자체의 특성, 빈 도, 내용이다. 이에 따른 구체적인 분석 항목은 상호 길이, 제품 묘사 정도, 지역 표현 정 도, 절대적으로 필요하지 않는 단어의 가감 여부, 약자 처리, 신조어로서 이것은 Kohli and Hemnes 의 연구(1995)에서 제시된 것이다. 그리고 우리나라 상호변경의 톡성을 연구하는 것 으로 상호의 법적 요인, 기업 집단에 따른 상호의 톻합과 분리, 언어를 분석하였다. 이에 대한 분석은 변경상호를 항목별로 분류하여 이의 변경전 상호와 변경후 상호를 비교하여 그 빈도와 비율을 구하는 것으로 이루어졌다. 그리고 항목별 사례 내용에 대한 특성 분석을 실 시하였다.

표본은 중권거래소에 상장되었거나 $\mathrm{KOSDAQ}$ 에 등뽁되었던 기업 중에서 1 회 이상의 상호변 경을 한 기업들의 상호이다. 증권거래소 상장 기업의 경우는 1958 년부터 2002 년 5 월 사이 에 1 희 이상의 상호변경을 한 기업 상호를 중권거래소의 변경 상장일 자료를 조사하여 표 본을 획득하였고 $\mathrm{KOSDAQ}$ 등록 기업은 1998 년부터 2002 년 5 월 사이에 $\mathrm{KOSDAQ}$ 의 상호변경 상장일 자료를 조사하여 표본올 구하였다. 상호변경 상장일을 표본의 선정 기준으로 삼은 것은 기업의 상호변경이 최초 보도되었거나 기업이 상호변경을 공시하였다 하더라도 실제 상호변경이 이루어지지 않은 경우가 예비 조사에서 다수 발견되었기 때문이다. 그리고 상호 는 기업이 마케팅 할동에서 부가가치룰 창출하기 위한 것이기 때문에 새로운 상호가 공식적 으로 사용되는 시점인 변경 상장일이 적절한 기준을 판단되었다. 다음으로 상호변경 상장일 표본의 신뢰성을 높이기 위해 중권시장지, KOSDAQ 시장지, 중권거래소 및 $\mathrm{KOSDAQ}$ 웹사이트 의 공시 사항, 주요 경제지, 중권회사 발간 자료 등의 확인울 통해 추가 점검을 하였다. 또 한 상호변경 상장일이라는 자료의 신빙성이 낮은 기업의 경우에는 해당 기업의 담당자에게 전화를 걸어 변경 상장일 여부를 확인하였다. KOSDAQ 등록 기업의 상호변경 상장일 기간을 1998 년 이후부터로 한 이유는 1997 년 이전에는 KOSDAQ 시장에서 상호변경이 드물게 일어났 으며 변경 상장일에 대한 정확한 자료를 획득하는 것이 거의 불가능했으며 벤처 투자 열풍 에 의한 KOSDAQ 시장 활성화가 1998 년 이후에 나타났기 때문이다. 하지만 증권거래소에 상 
장하거나 KOSDAQ 시장에 둥록하는 시점에서 상호률 변경한 기업의 상호는 표본에서 제외하 였다. 이렇게 한 이유는 소비자가 상호변경 기업의 이전 상호를 잘 모르고 있는 경우가 많 았고 해당 기업이 주가를 상숭시키기 위한 의도로 상호변경을 한 경우가 있었기 때문이다. 이렇게 하여 선정된 상호 표본의 연도별, 거래소별 빈도는 <표 2-1>, <표 2-2>와 같다. 중 권거래소에 상장되어 있는 기업의 상호변경 건수는 535 회이며 KOSDAQ 시장에 등록되어 있 는 기업의 상호변경 건수는 171 회이다. 이에 따라 본 연구에서 분석한 총 표본수는 706 개 이다.

<표 2-1> 1958 년부터 2002 년 5 월까지의 중권거래소 상장 기업의 상호변경 빈도수

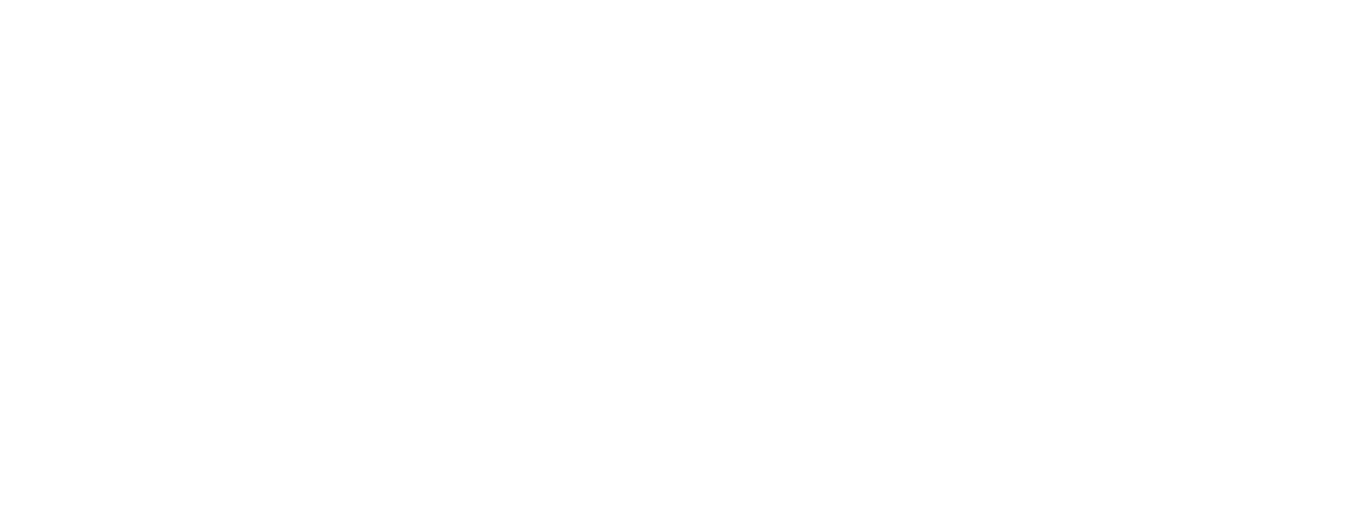

<표 2-2> 1998 년부터 2002 년 5 월까지의 KOSDAQ 등톡 기업의 상호변경 빈도수

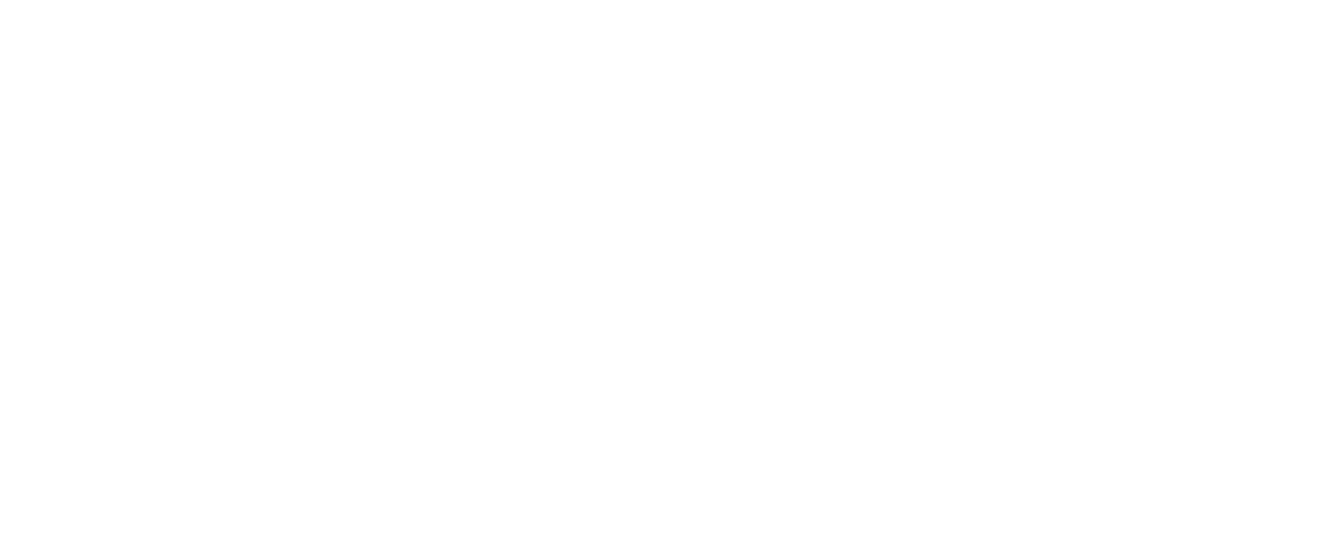

\section{4 분석 결과}

\section{4 .1 상호에 관련된 법적 요인}

분석에 앞서 우리나라 기업의 상호에 대한 이해를 돕기 위해 상호에 관련된 법적 사항들 을 제시하였다. 왜냐하면 우리나라에서 상호로 인정받으려면 법적 요건을 충족시켜야 하기 때문이다. 상호도 브랜드의 일종이므로 상표법의 적용을 받는다. 우리나라 상표법은 등록주 의를 채택하고 있으므로 상호 브랜드로 법적인 보호를 받는 가장 좋은 방법은 둥록을 하는 
것이다. 아무리 좋은 상호 브랜드라도 상표로 둥록해 놓지 않으면 해당 상호에 대한 배타적 권리를 인정받지 못할 수 있다.

상표로 인정받으려면 상호는 2 음절 이상으로 이루어진 명사형 단어이어야 한다. 만약에 등록하려는 상호가 다른 상호나 브랜드로 소비자가 오인하거나 혼동하는 경우에는 상호로 인정받지 못한다. 다음으로 일반명사, 저명한 지명만으로 된 상호는 상표로 인정되지 않으 며 사희 미풍양속에 반하는 단어로 된 상호는 상표로 둥록할 수 없다. 1997 년부터 영어로 된 브랜드명을 상표로 등록하는 것이 가능해졌는데 영문 브랜드명은 철자가 3 자 이상이어 야 하나 사용에 의하여 식별력을 가진 경우에 한해 철자가 2 자인 경우도 상표로 등록이 가 능하다. 이러한 사항은 상호에도 동일하게 적용된다. 이에 의해 LG, SK 와 같은 영문 브랜 드명이 상호 상표로 둥록되어 사용되고 있는 것이다(조혁근 2002).

\section{4 .2 상호변경의 유형과 빈도 분석}

우리나라 기업의 최초 상호변경 사례는 1958 년에 저축은행이 제일은행으로 상호룰 변경 한 것이다. 상호변경의 유형온 다양한 기준에 따라 분류가 가능한데 본 연구에서는 Kohli and Hemnes(1995)의 분류 방법을 원용하여 분석하였다. 그리고 분석의 심도를 더하기 위해 제조업과 서비스업으로 구분하여 분석하고 이률 종합하였다. 상호변경을 제조업과 서비스업 으로 나누어서 분석한 이유는 상호의 중요성과 상호변경이 미치는 영향이 업종에 따라 다르 게 나타날 수 있다고 판단했기 때문이다(Krishnan and Hartline 2001). 이는 제조업의 경우 에는 상호이외에 개별 제품이나 제품 계열별로 다른 브랜드가 사용되기도 하지만 서비스업 에 있는 기업의 경우에는 대부분이 상호만을 사용하고 있다(Keller 1998)는 현실을 반영하 기 위한 것이다. 제조업과 서비스업 분류 기준으로 통계청에서 제시하고 있는 표준산업분류 커드(Standard Industrial Classification Code, SIC)를 이용하였다. 추가적 분석으로 우리 나라에서 상호변경이 일반화되고 브랜드 자산의 중요성이 인식되기 시작한 시기라고 할 수 있는 1990 년을 기준으로 해서 89 년 이전과 90 년 이후로 나누어 상호변경의 시대적 특성을 파악하기 위해 연대 분석(chronological analysis)올 실시하였으며 이에 대한 분석 결과는 각 분석 항목 하단에 제시하였다. ${ }^{1)}$

분석 방법은 상호변경을 유형별로 나눈 다음에 해당되는 상호변경 사례의 빈도수와 비율 을 제조업과 서비스업으로 분류하여 구하였으며 이에 해당되지 않는 사례는 기타로 처리하 였다. 우리나라에서는 법제도상 상호변경에서 (주)금호건설을 금호건설(주), (주)SKC 를 $\mathrm{SKC}$ (주)로 하는 것과 같이 희사 유형의 표기 위치를 변경하는 것도 상호변경의 등록 대상인 데 이러한 유형의 상호변경은 기타로 분류하였다. 기타의 내용에 대해서 설명이 필요한 경 우에는 항목별 설명을 제시하였다.

<표 2-3> 상호의 길이 변화 빈도(비율) 분석

\begin{tabular}{|l|r|r|r|}
\hline \multicolumn{1}{|c|}{ 상호의 길이 } & 제조업(\$) & 서비스업(\$) & 전체(\$) \\
\hline 상호가 짧아진 경우 & $189(27)$ & $58(8)$ & $247(35)$ \\
\hline 상호가 길어진 경우 & $80(11)$ & $26(4)$ & $106(15)$ \\
\hline 기타 & $227(32)$ & $126(18)$ & $353(50)$ \\
\hline
\end{tabular}

1) 이에 대한 분석을 제안해 주신 익명의 심사자께 감사드립니다. 
바람직한 상호는 상호의 길이가 짧거나 단순해야 한다고 한다(Keller 1998). 상호 길이 변화률 분석해 보면 상호 길이의 변동이 없는 경우가 $50 \%$ 로 가장 많았으며 상호의 길이가 잛아진 경우가 $35 \%$, 길어진 경우가 $15 \%$ 로 나타났다. 이는 기업들이 변경된 상호로 기존 상 호의 길이를 줄인 것을 사용하는 빈도가 길어진 것을 사용하는 빈도보다 높다는 것을 의미 한다. 업종별 톡성으로 서비스업보다는 제조업에 있는 기업의 변경상호가 짧아진 현상이 높 게 나타났다. 이를 통해 우리나라 기업의 상호변경에서 상호 길이의 단축 현상이 확대 현상 보다 높게 나타나며 이러한 현상은 제조업에서 강하게 나타난다는 것을 알 수 있다. 기타로 는 회사 유형 표기 위치 변경이 다수를 차지하였다. 연대 분석에서 89 년 이전에는 짧아진 경우가 80 건(11\%), 길어진 경우가 12 건(2\%)이었으며 90 년 이후에는 짧아진 경우가 167 건 (24\%), 길어진 경우가 94 건(13\%)으로 나타넜다. 90 년 이후에 변경상호가 길어진 경우가 증 가한 것은 90 년 이후 상표 둥록이 급중하여 상호 길이를 줄이는 것이 용이하지 않다는 사 실을 반영해 주는 것이다.

<표 2-4> 상호의 제품 묘사 정도 빈도(비율) 분석

\begin{tabular}{|l|r|r|r|}
\hline \multicolumn{1}{|c|}{ 상호의 제품 묘사 정도 } & 제조업(\$) & 서비스업(\%) & 전체(\%) \\
\hline 제품 묘사를 제거하거나 덜 구체적으로 한 경우 & $317(45)$ & $105(17)$ & $422(60)$ \\
\hline 제품 묘사를 보다 구체적으로 한 경우 & $110(16)$ & $47(7)$ & $157(22)$ \\
\hline 기타(제품 묘사와 관련없는 경우) & $69(10)$ & $58(8)$ & $127(18)$ \\
\hline
\end{tabular}

상호의 제품 묘사 정도는 변경된 상호가 기존 상호에 비하여 기업의 사업 영역이나 제품 을 나타내는 정도를 의미하는 것으로 이것은 상대적인 구분이다. 변경된 상호에서 업종이나 제품 묘사를 제거하거나 덜 구체적으로 한 경우가 $60 \%$, 구체적으로 한 경우가 22\%로 나타났 다. 서비스업보다는 제조업의 상호에서 제품 묘사 정도가 감소하는 경향이 높게 나타났는데 이는 제조업에서의 특정 제품(군) 탈피 정도가 서비스업보다 더 많이 이루어졌다는 것을 시 사해주는 것이다. 기업이 성장하고 사업 영역이 확대되거나 제품 종류가 많아질수록 제품 묘사를 제거하거나 덜 구체적으로 하는 경향이 있다(Keller 1998). 반면에 기업이 사업이나 제품을 전문화할수록 제품 묘사적인 상호를 사용하거나 제품 묘사를 구체적으로 한 상호로 변경하는 경향이 있다. 추가적 분석 결과, 대기업의 변경상호는 제품 묘사가 없거나 덜 구 체적인데 비하여 중소기업이나 전문 기업의 상호는 제품 묘사 정도가 높거나 구체적이다는 것을 알 수 있었다. 연대 분석에서 89 년 이전에는 제품 묘사가 감소한 경우가 85 건(12\%), 구체화된 경우가 35 건(5\%)이었으며 90 년 이후에는 감소한 경우가 337 건(48\%), 구체화된 경우가 122 건(17\%)으로 나타났다. 이를 통해 제품 묘사 정도에는 연대별로 큰 차이가 나타 나지 않으며 모두 감소했다는 것을 알 수 있다.

<표 2-5> 상호의 지역 표현 정도 빈도(비율) 분석

\begin{tabular}{|l|r|r|r|}
\hline \multicolumn{1}{|c|}{ 상호의 지역 표현 정도 } & 제조업(\%) & 서비스업(\%) & \multicolumn{1}{|c|}{ 전체(\%) } \\
\hline 지역 표현을 제거하거나 덜 구체적으로 한 경우 & $69(10)$ & $39(6)$ & $108(16)$ \\
\hline 지역 표현을 보다 구체화한 경우 & $7(1)$ & $6(1)$ & $13(2)$ \\
\hline 기타(지역과 관련없는 상호) & $420(59)$ & $165(23)$ & $585(82)$ \\
\hline
\end{tabular}

변경된 상호가 지역이나 지명을 나타내는 정도는 감소하였다. 상호의 지역 표현 정도 분 
석 결과, 지역 표현을 제거하거나 덜 구체화한 경우가 $16 \%$, 지역 표현을 구체화한 경우가 $2 \%$ 로 나타넜다. 업종별로는 서비스 상호보다 제조업 상호의 지역 표현 감소 정도가 구체화 한 경우보다 높게 나타났다. 상호의 지역 표현 정도의 적절성은 기업의 사업 특성에 의해 결정된다. 제품이나 원료의 원산지가 중요하거나 소비자가 특정 지역, 지명을 나타내는 제 품울 선호하는 경우에는 상호에 지역 표현울 나타내는 것이 바람직할 수 있다. 일본의 경우 에 전통 식품, 한방 의약품에는 지역을 나타내는 한자 상호가 여전히 사용되고 있는데 우리 나라의 상호에서도 이러한 현상은 나타난다. 우리나롸 상호에 지역 표현이 들어가 있는 경 우의 상당수는 기업의 지역 연고에 기인하는 것이다. 상호를 비지역적 상호로 변경하는 경 우는 기업이 지역 시장을 탈피하여 시장올 확대하거나 특정 지역명 상호가 소비자의 부정적 인 반웅을 유발시키는 경우이다. 연대 분석에서 89 년 이전에는 지역 표현이 감소한 경우가 30 건(4.2\%), 구체화된 경우가 9 건(1.3\%)이었으며 90 년 이후에는 감소한 경우가 78 건(11\%), 구체화된 경우가 4(0.6\%)으로 나타났다. 이는 이전에 비하여 90 년 이후에 상호변경에서 지 역 표현 감소 경향이 구쳬화하는 것보다 높게 나타난다는 사실을 반영해 주는 것이다.

<표 2-6> 절대적으로 필요하지 않은 단어의 가감 여부 빈도(비욜) 분석

\begin{tabular}{|l|r|r|r|}
\hline 절대적으로 필요하지 않은 단어의 가감 여부 & 제조업(\$) & 서비스업(\$) & 전체(\$) \\
\hline 절대적으로 필요하지 않은 단어를 상호에서 제거 & $214(30)$ & $39(6)$ & $253(36)$ \\
\hline 절대적으로 필요하지 않은 단어를 상호에 추가 & $27(4)$ & $13(2)$ & $40(6)$ \\
\hline 기타(이와 관련없는 경우) & $255(36)$ & $158(22)$ & $413(58)$ \\
\hline
\end{tabular}

우리나라 상호에 많이 사용되는 단어로서 절대적으로 필요하지는 않는 단어라고 할 수 있 는 어휘로는 제일, 한국, 대한, 코리아, 고려, 조선, 종합, 산업, 공업, 인더스트리, 테크 놀러지 등이 있다. 이들 단어는 기업의 사업이나 제품 특성을 소비자에게 전달해 주는데 한 계가 있으며(Ries and Ries 1998), 이들 단어를 이용해서 기업올 차별화하는 것도 용이하지 않다. 왜냐하면 위에 제시된 단어가 원래는 좋은 의미를 가지고 있다고 하더라고 상호에 흔 하게 사용되고 있어 독특성이나 차별성을 주기 어렵기 때문이다. 미국의 상호에서도 General, US, America, First, Consolidated, Industry, Technology 등이 이에 해당하는 단 어이다. 이들 단어가 상호에 포함되어 있는 미국 기업들의 상당수는 규모가 큰 희사로서 사 업 범위가 넓고 제품이 매우 다양하며 널리 알려진 회사라는 특징이 있다. 따라서 이와 유 사한 특징이 있는 우리나라 기업이 이런 단어률 포함한 상호로 변경하는 것은 고려해 볼 수 있는 대안이다. 하지만 근래에 미국에서 이런 단어를 포함하고 있는 상호의 변경이 이루어 지고 있다. Consolidated Foods 가 Sara Lee 로 상호를 변경한 것이 이에 해당되는 예이다. 우리나라에서도 불필요한 단어를 상호에서 제거하는 현상이 나타나고 있다. 조선맥주가 Hite 맥주로 상호를 변경한 것이 이런 경우이다. 분석 결과, 상호에서 절대적으로 필요하지 않은 단어를 제거한 경우가 $36 \%$, 추가한 경우가 6\%로 나타넜다. 업종별로는 제조업에서 절 대적으로 필요하지 않은 단어률 상호에서 제저하는 정도가 서비스업보다 높게 나타넜다. 연 대 분석에서는 89 년 이전에는 필요하지 않은 단어가 제거되는 경우가 82 건(12\%), 추가되는 경우가 13 건(2\%)이었으며 90 년 이후에는 제거되는 경우가 171 건(24\%), 추가되는 경우가 27 건 (4\%)으로 나타넜다. 
<표 2-7> 상호의 약자 처리 빈도(비율) 분석

\begin{tabular}{|l|r|r|r|}
\hline 상호의 약자 처리 & 제조업(\$) & 서비스업(\$) & 전체(\$) \\
\hline 상호를 약자로 처리한 경우 & $104(15)$ & $33(5)$ & $137(19)$ \\
\hline 약자 처리한 상호를 확장한 경우 & $11(1.6)$ & $3(0.4)$ & $14(2)$ \\
\hline 기타(약자 처리와 관련 없는 상호) & $381(54)$ & $174(25)$ & $555(79)$ \\
\hline
\end{tabular}

상호를 약자로 처리하는 유형은 두가지로 나눌 수 있다. 하나는 상호를 국어 약자 처리하 는 것으로 고려합섬이 고합으로, 서울통상이 서통으로 상호률 변경한 경우가 이에 해당한다. 다른 하나는 상호를 영어 약자로 처리하는 것으로 한국나이롱이 Korea Nylon 의 약자인 코 오롱(Kolon), 서울방송이 SBS 로, 한국전기통신공사가 KT 로 상호변경을 한 경우이다. 1990 년 이전에는 국어 약자로 상호를 변경한 사례가 상당수 존재하였으나 근래에는 영어 약자로 상호를 변경하는 현상이 중가하고 있다. 분석 결과, 상호룰 약자로 처리한 경우가 15\%이었 으며 이의 대부분이 영문 약자이었으며, 약자 처리한 상호를 확장한 경우는 $2 \%$ 이었다. 업종 별로는 제조업보다 서비스업 상호에서 상호롤 약자로 처리한 경우의 정도가 반대 경우에 비 해 높게 나타넜다. 연대 분석에서 89 년 이전에는 약자 처리의 경우가 8 건(1.1\%), 약자 확 장의 경우가 1 건(0.1\%)이었으며 90 년 이후에는 약자 처리가 129 건(18.3\%), 약자 확장이 13 건(1.8\%)으로 나타났다.

<표 2-8> 상호의 신조어 정도 빈도(비율) 분석

\begin{tabular}{|l|r|r|r|}
\hline 상호의 신조어 정도 & 제조업(\%) & 서비스업(\%) & \multicolumn{1}{|c|}{ 전체(\$) } \\
\hline 상호를 신조어로 변경한 경우 & $177(25)$ & $47(7)$ & $224(32)$ \\
\hline 신조어를 상호에서 탈락시킨 경우 & $7(1)$ & $5(1)$ & $12(2)$ \\
\hline 기타(신조어와 관련 없는 상호) & $312(44)$ & $158(22)$ & $470(66)$ \\
\hline
\end{tabular}

상호는 새로운 단어를 만들어내는 원천 중에 하나이다. 이전에 국어나 영어 등에 없었던 단어가 신조어 상호로 만들어져 널리 사용되기도 한다. 근래에 브랜드의 중요성이 높아지고 인터넷이 일반화됨에 따라 좋은 브랜드명과 도메인명(domain name)을 미래의 상호 후보로 미리 확보해 놓고자 하는 의도에서의 상표, 상호, 도매인 출원과 등록이 급증하였다. 이로 인해 기존의 단어를 이용한 상호 개발이 한계에 부딪히자 이의 타개책으로 나온 것이 신조 어 상호이며 이에 따라 신조어 상호가 급증하고 있다. 분석 결과, 상호를 신조어로 변경한 경우가 $32 \%$ 이었으며 대부분이 영어 신조어 상호였다. 반대로 신조어를 상호에서 탈락시킨 경우는 2\%이었다. 업종별로는 제조업에서 신조어 상호를 사용하는 정도가 서비스업의 상호 보다 높게 나타났다. 연대 분석에서 89 년 이전에는 신조어로 변경한 경우가 20 건(2.8\%), 신조어를 탈락시킨 경우가 1 건(0.1\%)이었으며 90 년 이후에는 신조어로 변경한 경우가 204 건(28.9\%), 탈락시킨 경우가 11 건(1.6\%)으로 나타났다. 이는 90 년 이후에 상표 등록이 급 증하고 일반단어 상호 등록이 어렵계 되자 이를 극복하기 위해 신조어 상호로 상호변경이 급증했다는 것을 반영해 주는 것이다.

다음은 우리나라 상호변경에서 주로 나타나는 현상에 대한 분석이다. 우리나라 기업들의 상당수는 모기업을 중심으로 한 기업 집단 형태로 구성되어 있다는 특징이 있다. 1990 년 이후에 대기업들의 CIP 가 활발하게 이루어지면서 상호변경이 많이 이루어졌다. 이전까지 모기업과 다른 상호률 사용하던 계열사들의 상호가 모기업 상호와 동일하거나 유사한 상호 
로 통합하기 위한 상호변경이 상당수 이루어졌다. 하지만 1997 년 IMF 사태 이후에 모기업 상호에서 벗어나 다른 상호로 변경하는 현상이 발생하고 있다. 이에 변경된 상호가 모기업 상호로 퉁합된 경우와 분리된 경우를 나누어 분석을 하였다.

<표 2-9> 모기업 상호와 통합 또는 분리 빈도(비율) 분석

\begin{tabular}{|l|r|r|r|}
\hline \multicolumn{1}{|c|}{ 모기업 상호와 통합 또는 분리 } & 제조업(\$) & 서비스업(\$) & 전체(x) \\
\hline 모기업 상호로 통합 & $175(24)$ & $79(11)$ & $254(35)$ \\
\hline 모기업 상호에서 분리 & $33(5)$ & $13(2)$ & $46(7)$ \\
\hline 기타(모기업과 상관없는 경우) & $288(41)$ & $118(17)$ & $406(58)$ \\
\hline
\end{tabular}

분석 결과, 모기업 상호로 통합된 경우가 $35 \%$ 로 나타났으며 모기업 상호에서 분리된 경우 가 7\%로 나타났다. 이는 우리나라 기업의 상호변경에서 나타나는 특이한 현상으로 상호변경 의 주원인 중에 하나가 모기업 상호와 통합하기 위한 것이라는 사실을 나타내 주는 것이다. 제조업과 서비스업의 상호변경에서 상호 분리보다는 상호 통합이 모두 높게 나타넜으며 업 종별 차이는 발견되지 않았다. 이는 우리나라 대기업들이 제조업과 서비스업 모두에 걸쳐 상호 분리보다는 통합을 많이 해 왔다는 것을 시사해 주는 것이다. 또한 이것은 우리나라 대기업들이 제조업과 서비스업라는 업종 구분 없이 지속적으로 사업 영역을 확대해 왔다는 것과 모기업 상호의 후광을 입는 것이 기업 가치를 상숭시키고(송영균 1991), 시장에서 여 러가지 유리한 점이 있기 때문에 상호 퉁합을 해왔다는 것을 확인해 주는 것이다. 하지만 모기업이 부실화된 경우에 계열사들은 부담이 되는 모기업 상호에서 탈피하여 독자 상호로 변경하는 현상이 근래에 나타나고 있다. 이러한 예로서 쌍용중공업이 STX 로, 대우전자부품 이 파츠늑(Partnic), 현대전자산업이 하이늑스(Hynix) 반도체로 상호률 변경한 사례가 있다. 연대 분석에서 89 년 이전에는 모기업 상호로 통합된 경우가 80 건(11.3\%), 모기업 상호에서 분리된 경우가 4 건(0.6\%)이었으며 90 년 이후에는 통합된 경우가 174 건(24.6\%), 분리된 경 우가 42 건(5.9\%)으로 나타났다. 이는 IMF 사태 이후에 기업 구조 조정으로 모기업 상호에서 분리하는 계열사가 이전보다 중가했다는 사실을 반영해 주는 것이다.

다음은 우리나라 변경상호의 표현 언어에 대한 분석이다. 현재 우리나라 기업 상호의 대 부분은 한자어, 영어 또는 이들 언어가 결합되어 이루어진 것이다. 1990 년 이후에 영어로 된 상호를 사용하는 경향이 중가하고 있으며 변경상호의 언어로 영어가 상당수를 차지하고 있다. 이는 비영어권 소비자들이 영어 브랜드명을 선호하는 경향이 증가하고 있다는 사실 (Zhang and Schmitt 2001)에 우리나라 기업들이 대옹하면서 나타난 현상이라고 사려된다. 예전에는 한글 상호명도 다소 존재하였으나 현재는 명맥만 유지하고 있는 실정이다. 변경된 상호 중에서 순한글 상호는 1982 년에 대일유업에서 빙그레, 1996 년에 오뚜기식품에서 오뚜 기로 변경한 사례 2 개뿐이다. 하지만 최근에 상호의 언어 차별화 차원에서 한빛, 우리, 으 뜸, 한솔 등과 같은 순한글 단어를 상호에 넣어 사용하는 사례가 나타나고 있다.

변경상호 언어 분석 결과, 한자어 상호가 $45 \%$, 영어가 $26 \%$, 복합어 상호(한자어+영어 또 는 영어+한자어)가 $24 \%$, 기타 상호가 $5 \%$ 로 나타났다. 제조업의 경우에는 한자어 상호가 가 장 많았으나 영어 상호도 상당한 비중을 차지하고 있었다. 반면에 서비스업 상호에서는 한 자어 상호가 영어 상호보다 상당히 높게 나타났다. 서비스업에서는 신뢰성을 줄 수 있는 상 호가 좋은데 이것을 우리나라 기업들은 한자어 상호로 표현하고 있다는 것을 나타내 주는 것이다. 연대 분석에서 89 년 이전에는 한자어로의 상호변경이 118 건(11.7\%), 영어로의 경 
우가 6 건(0.82\%), 한자어+영어로의 경우가 26 건(3.7\%), 기타의 경우가 1 건(0.1)이었으며 90 년 이후에는 한자어의 경우가 203 건(28.8\%), 영어의 경우가 177 건(25.1\%), 한자어+영어 가 140 건(19.8\%), 기타의 경우가 35 건(5\%)로 나타넜다. 이는 90 년 이후에 영어나 영어가 들어있는 복합어로의 상호변경이 급증했다는 것을 나타내 주는 것이다.

<표 2-10> 상호의 언어 유형 빈도(비율) 분석

\begin{tabular}{|l|r|r|r|}
\hline \multicolumn{1}{|c|}{ 언어 유형 } & 제조업(\$) & 서비스업(\$) & \multicolumn{1}{|c|}{ 전체(\$) } \\
\hline 한자어 & $218(31)$ & $103(14)$ & $321(45)$ \\
\hline 영어 & $140(20)$ & $43(6)$ & $183(26)$ \\
\hline 한자어+영어 또는 영어+한자어 & $119(17)$ & $47(7)$ & $166(24)$ \\
\hline 기타(순한글, 한글+영어, 한글+한자어 등) & $19(3)$ & $17(2)$ & $36(5)$ \\
\hline
\end{tabular}

\section{3. 결론}

\section{1 연구 결과의 요약}

상호가 기업 성공의 절대적인 요인은 아니지만 좋은 상호는 기업의 마케팅 비용을 절감시 켜 주고 경쟁 우위를 제공해 줄 수 있다(Robertson 1989, Keller 1998). 상호변경에 대한 기존의 마케팅 연구가 미국 기업의 상호를 대상으로 한 것이었으며(Kohli and Hemnes 1995), 우리나라 기업들의 상호변경 특성과 내용에 대한 연구가 부족하였다. 이에 본 연구에서는 우리나라 기업의 상호변경 사례를 분석하였다. 본 연구에서 밝혀진 사실을 요약하면 다움과 같다.

상호의 길이는 길어진 경우보다 짧아진 경우가 많았다. 상호의 사업 또는 제품 묘사 정도 는 이전의 구체적인 묘사형 상호에서 묘사어률 제거하거나 덜 구채적인 단어로 변경하는 경 우가 반대의 경우보다 많았다. 상호의 지역 표현 정도는 현저히 감소하였으며, 절대적으로 필요하지 않은 단어를 상호에서 제거하는 현상이 반대 경우보다 높게 나타났다. 상호의 약 자 처리 현상은 높게 나타났는데 이는 상호를 짧게 하려는 의도에서 나타난 현상이다. 상호 를 신조어로 변경한 사례가 신조어를 상호에서 탈락시킨 경우보다 높게 나타났다. 우리나라 기업의 상호변경 특성으로 모기업 상호와 통합하기 위하여 계열사들의 상호률 모기업 상호 로 변경하는 사례가 많이 나타났다. 하지만 근래에 계열사들이 모기업 상호에서 탈피하여 독자 상호로 변경하는 현상이 나타나고 있다. 그리고 변경된 상호의 대부분이 한자어나 영 어 상호이었으며 근래에 영어 상호로 변경하는 경우가 중가하고 있는데 이는 시장 확대, 소 비자 선호, 전자상거래의 영향을 반영해 주는 것이다. 제조업과 서비스업으로 나누어 상호 변경을 분석했을 때 이러한 현상의 대부분이 제조업 상호에서 더 강하게 나타넜다.

\section{2 바람직한 상호변경 및 상호 브랜드에 대한 논의}

마케팅에서 이루어진 바람직한 브랜드명에 대한 연구들은 몇몇울 제외하고(Robertson 
1989, Kohli and Hemnes 1995, Keller, Heckler, and Houston 1998), 대부분이 직관적, 규 범적, 예시적이다(Aaker 1991, 1996, Kot ler 1994, Keller 1998). 바람직한 브랜드명은 간 단하고 발음하거나 철자(spel1)하기 쉬워야 하며, 친숙하고 의미가 있어야 하며, 다르고, 차별적이고, 독특해야 하며, 제품 편익을 암시해야 한다. 그리고 움직임이나 색상과 같은 제품 품질을 나타내야 하며, 알아들고 기억하기 쉅고 짧아야 하며, 외국에서나 외국어로서 좋지 않은 뜻을 내포하고 있어서는 안 된다고 한다(Kotler 1994, Keller 1998). 이런 톡성 들을 많이 가지고 있는 브랜드명일수록 브랜드 인지도는 향상되고 긍정적인 연상은 증가하 는데(Keller 1998), 상호도 이와 유사하다. 이에 본 연구의 결론에서 우리나라 기업의 상호 변경 사례의 분석 결과와 분석에서 개별적으로 다루지 못한 사례들을 토대로 바람직한 상호 변경 및 상호 브랜드의 특성 요소에 대하여 논의해 보고자 한다. 제시된 논의 사항들은 브 랜드명에 관한 연구와 마케팅, 소비자행동, 심리학, 언어학에 관련된 문헌과 기업 전략, 기 업 아이덴티티 전문 자료에 근거한 것이다(Robertson 1989, 01 ins 1989, Room 1991 , Fombrun 1996, Keller 1998).

\section{2 .1 약자 상호는 특별한 경우가 아니면 피하는 것이 줗다.}

분석 결과, 우리나라에서 상호를 야자 상호로 변경하는 빈도가 근래에 중가한 것으로 나 타났다. IBM, GM, 3M, P\&G, AT\&T, Nabisco, Fedex 와 같은 상호가 널리 알려진 약자 상호이 다. 약자 상호를 사용하기 위해서는 원래 상호가 널리 알려져 있거나 원상호가 약자로 통용 되고 있어야 한다는 전제가 있어야 한다(Kohli and Hemnes 1995). IBM 이 International Business Machines, GM 이 General Motors 의 약자 상호라는 것은 우리나라 소비자들도 알고 있는 사실이다. 그런데 우리나라에서 변경상호로 사용되고 있는 SNG21, GPS, NSF, 아이에이 치아이시, 케이씨티시, 브이케이라는 상호의 기업이 무슨 사업을 하고 무슨 제품올 마케텅 하며, 소비자에게 어떤 편익을 제공하는 회사라고 자신있게 이야기 할 수 사람이 몇이나 있 을지 의문이다. 하지만 LG 는 Lucky Goldstar, SK 는 선경, BYC 는 백양이라는 원상호의 약 자로 만들어진 상호라는 것은 웬만한 소비자들도 알고 있는 사실이다. 이렇게 된 데에는 약 자 상호를 시장에 널리 알리기 위한 마케팅 캠패인에 기업의 상당한 자원 투자가 있었고 소 비자의 원상호 인지도가 높았다는 뒷받침이 있었다.

마케텅 담당자들은 약자 상호는 짧으므로 소비자가 쉅게 기억할 것이라고 생각하는 경향 이 있다. 하지만 소비자가 짧다(short)고 생각하는 것과 간단하다(simple)고 생각하는 것이 다를 수 있다는 점을 고려해 보아야 한다. iloveschool 이라는 상호와 ILS 라는 상호 중에 어느 것이 보다 간단하고 기억하기 웝게 느껴지는 지를 생각해 보면 될 것이다. 소비자는 짧은 상호보다 간단한 상호를 더 선호한다는 사실을 간과해서는 안될 것이다.

분석 결과, 변경상호로 영어 약자 상호가 증가하는 것으로 나타났는데 이에는 신중함이 요구된다. 상호로 약자 영문자를 사용하는 경우에는 가능하면 3 문자 이하로 하는 것이 좋 다. 사람은 어떤 논리적 관계가 없는 4 개 이상의 문자률 연결시켜 기억하는데 정보 처리상 어려움을 느낀다(Robertson 1989). 이는 널리 알려진 약자형 영문 상호의 대부분이 3 자 이 내라는 사실에서도 알 수 있다. 그러므로 약자 영문 상호는 가능하면 3 문자 이내로 해야 하는데 알파벳의 2 개 문자로 만들어 낼 수 있는 상호는 676 개, 3 개 문자는 17,576 개 밖 에 되지 않으며 이에 아라비아숫자(0-9)를 더한다 해도 1,296 개, 46,656 개의 상호밖에 만 들어 낼 수 없다는 한계가 있다. 다음으로 상호를 약자로 사용하려면 그것이 의미하는 것을 소비자들이 잘 알고 있거나 그것을 시장에 널리 알릴 수 있는 충분한 마케팅 자원이 있는지, 
그리고 등록 가능한지 숙고해 보는 것이 좋다. 이에 따라 약자 영문 상호는 $\mathrm{KT}, \mathrm{SK}, \mathrm{LG}$ 와 같은 대기업의 상호로서 가능한 대안이라는 것을 알 수 있다.

그러면 약자 상호의 이러한 단점을 극복할 수 있는 방안은 없는가에 대하여 생각해 볼 펼 요가 있다. 약자 상호는 두가지 유형이 있는 데 하나는 위에서 설명한 두문자형 약자 상호 이다. 다른 하나는 원상호를 구성하는 음절이나 문자률 발음하기 좋고 기억하기 쉬운 형태 로 축약시킨 신조어 상호가 있다. 신조어 상호는 아이덴티티를 나타내기 쉽고, 법적 보호률 받기가 용이하며, 사업 확장에 제한이 없다는 장점이 있다(Kohli and Hemnes 1995). 이러한 상호로 외국의 경우에는 National Biscuit Company 가 Nabisco 로, Federal Express 가 Fedex 로 변경한 경우가 있으며, 우리나라에서는 포항종합제철이 Posco 로 상호롤 변경한 경 우가 있다. 상호를 약자로 변경하는 경우에는 이처럼 윈상호를 구성하는 국어/영어의 음절 이나 문자를 창조적으로 결합시켜 신조어 상호로 개발하는 방법을 고려해 볼 수 있다. 하지 만 이 경우에도 개발된 상호를 인지시키기 위한 비용이 소요되며 원상호와의 연결 고리가 약할 경우에는 소비자가 원상호에 대하여 갖고 있는 호감을 상실할 수 있다는 위험이 있다.

\section{2 .2 상호의 언어 특성을 이해하고 활용하라.}

분석 결과, 무의미 신조어 상호와 영어 상호가 중가한 것으로 나타났다. 상호는 사업체의 이름으로 언어로 표현된다. 언어는 사물, 관념 등을 지칭하거나 표현하는 기호 체계이다. 상호도 하나의 언어 기호이므로 상당 부분 언어 이론에 기반을 둔다. 언어는 의미론 (semantics), 음성론(phonetics), 형태론(morphemes), 구조론(syntax) 부분으로 구성되어 있는데 이 중에서 상호에 주로 관련되는 부분은 의미론, 음성론, 형태론이다. 상호는 구문 체계가 아니므로 구조론은 그다지 중요하지 않다.

의미론적으로 브랜드명은 의미의 정도에 따라 브랜드명 스퐥트럼(brand name spectrum)으 로 구분한다(Murphy 1990). 브랜드명 의미는 제품에 대한 모사적 브랜드명에서 브랜드명 자 체에는 원래 의미가 없는 신조어 브랜드명까지 그 의미 정도가 다양한데(Keller 1998), 상 호의 의미 정도도 이와 유사하다. 우리나라의 변경상호를 브랜드명 스펙트럼에서 보면 벨로 체 피아노(Veloce Piano)는 제품 묘사적 상호이고 농심은 제시적 상호이며, 알덱스, 파루는 신조어로서 본래는 의미가 없는 상호라고 할 수 있다. 바람직한 상호가 되려면 의미가 있어 야 한다(Robertson 1989). 여기서 의미는 기업이 소비자에게 제공하는 본질적인 편익이나 소비자가 기대하는 것과 관련이 있어야 한다는 것으로 해석할 수 있다(Keller, Heckler, and Houston 1998). 의미가 있는 상호를 소비자는 쉅게 이해하고 잘 기억하는 경향이 있다. 원래 상호에 의미가 없는 경우에 기업은 상호를 통해 포지셔닝하고자 하는 것을 자유롭게 정할 수 있고 소비자 기호 변화에 신축적으로 대처할 수 있다는 장점이 있으나 소비자가 원 하는 핵심 편익을 나타내는 의미가 있는 상호보다 마케팅에 시간과 비용이 더 든다는 단점 이 있다. 의미 측면에서 상호는 기업의 규모, 사업 영역, 소비자에게 제공하는 편익에 따라 브랜드명 스펙트럼상에서 적절한 의미 수준을 결정하는 것이 바람직하다. 기업의 규모가 크 고, 사업이 다각화되어 있으며, 제품의 중류가 다양한 경우에는 제품 묘사적 상호는 바람직 하지 않다. 왜냐하면 기업이 사업을 확장하거나 다양한 제품을 마케팅하는 경우에 상호가 특정 사업/제품과 강하게 연결되어 있다는 연상이 강하면 곤란을 격을 수 있기 때문이다. 이런 경우에는 의미없는 신조어나 제시적 의미의 상호가 바람직하다. 이런 예로서 미원이 사업을 확장하면서 상호를 대상으로 변경한 것은 현명하게 대처한 것이라고 할 수 있다. 많 은 계열사를 거느리고 다양한 사업을 전개하고 있는 우리나라 대기업들의 상호 대부분이 신 
조어나 제시적 상호라는 것도 이와 같은 이치이다. 반면에 기업이 톡정 사업이나 제품에 전 문화되어 있고 해당 사업올 지속적을 영위하고자 한다면 제품 묘사적 상호가 바람직할 수 있다. 이러한 경우에는 상호가 기업이 영위하는 사업 또는 제품 범주를 나타내주면 더욱 줗 다(Keller, Heckler, and Houston 1998). 브랜드 컨셉율 기능적, 경험적, 상징적 컨셉으로 구분할 수 있는데(Park, Jaworski, and MacInnis 1986), 소비자에게 제공하는 편익의 컨셉 과 상호를 일치시키는 것도 하나의 방법이 될 수 있다. 기능적 컨셉 제품을 마케팅하는 기 업은 제품 묘사적 상호가 바람직하고 경헙적 제품의 경우는 감각적 상호가, 상징적 제품은 은유적 상호가 좋을 것이다.

상호는 음성으로도 지각된다. 사람들은 원래 아무런 의미가 없는 브랜드명의 경우에도 브 랜드명의 음성 상징에 따라 의미를 추론한다(Robertson 1989). 브랜드명의 음성 특성에 따 른 소비자 의미 추론과 반웅은 음성론의 음성 상징(sound symbolism)으로 연구가 되었다 (Klink 2000). 영어 모음에서 a, o, u는 e, i 에 비해서 큰 사물과 느리고 무게있는 움직임 을 나타내며, $\mathrm{e}, \mathrm{i}$ 는 작은 사물과 역동적인 움직임을 나타내는 것으로 알려져 있다 (Robertson 1989). 또한 발음시 혀가 전방위에 있는 모음은 후방위 모음보다 빠르고, 가볍 고, 부드럽고, 여성적으로 지각되고 후방위 모음은 이와 반대로 지각되는 경향이 있다 (Klink 2000). 이러한 현상은 우리나라 상호에서도 나타날 것이라고 판단된다. 왜냐하면 한 글이 영어와 같은 표음 문자이고 국어에 한자를 사용하는 정도가 이전과 비교하여 현저히 감소했기 때문이다. 국어에서 에, 애, 이는 영어의 $\mathrm{e}, \mathrm{i}$ 와 아, 오, 우는 $\mathrm{a}, \mathrm{o}, \mathrm{u}$ 와 음성 이 유사하므로 영어 모음과 비숫한 의미률 나타낼 것으로 사려되며 중간 발음인 으, 어는 중성적인 의미를 나타낼 것으로 예상된다.

영어 자음도 음성 상징이 있다(Klink 2000). 영어에서 마찰음( $f, s, v, z)$ 은 폐쇄음(p, t, $\mathrm{b}, \mathrm{d}, \mathrm{g}, \mathrm{k}$ )에 비하여 작고, 빼르고, 가볍고, 여성적으로 지각되며, 무성 폐쇄음 $(\mathrm{p}, \mathrm{t}, \mathrm{k})$ 은 유성 폐쇄음(b, d, g)에 비하여 작고, 빠르고, 가볍게 지각되고, 무성 마찰음(f, s)은 유성 마찰음 $(\mathrm{v}, 2)$ 에 비하여 르고, 부드럽고, 여성적으로 지각된다고 한다. 이를 국어에 적용하면 한글에서도 영어와 유사한 자음의 경우에는 이와 비슷한 현상이 나타날 것이다. 따라서 상호변경에 필요한 상호 개발에 음성 상징을 활용하면 효울성을 높이고 소기의 성과 를 달성할 수 있을 것이다. 특히 근래에 변경상호나 신상호로 영어 상호가 중가하고 신조어 상호가 늘어남에 따라 음성 상징이 더욱 중요해졌다. 웨냐하면 원래 의미가 없는 신조어 상 호에 대한 소비자 지각은 상호의 음성 상징에 영향을 받는 정도가 높기 때문이다. 상호에서 음성 상징을 활융하는 방법은 기업의 이미지나 영위하는 사업과 마케팅하는 제품들의 특성 과 이에 맞는 의미의 음성이나 음소를 적절하게 결합하는 것이다. 다른 방안으로 기업이 추 구하는 아이덴티티에 적절한 음성/음소를 추출하고 다음으로 이률 구성하는 음소/문자들을 창의적으로 결합한 것올 상호로 하는 것도 좋은 방법이 될 수 있다.

형태론은 언어의 어의 형태소가 결합되는 방식과 이에 따른 의미를 연구하는 분야이다. 단어는 어의소가 결합되어 이루어진 것인데 변경상호의 상당수도 어의 형태소가 결합되어 만들어진 것이다. 쳐근에 기존 단어를 결합한 브랜드명 개발이 한계에 부딫히자 어의 형태 소를 창의적으로 결합한 브랜드명이 외국에서 중가하고 있다(자동차의 예: Movano, Unanima). 이러한 현상은 근래의 우리나라 변경상호에서도 나타나고 있다(예: Mirpia, Intellitech). 상호에서 형태론을 활용하는 방법은 기업이 상호를 통해 표현하고자 하는 의 미를 결정한 다음에 이 의미에 해당하는 어의 형태소률 소비자가 이해하는 언어들(한글, 한 자, 영어 등)을 대상으로 추출하고 이를 철자법을 고려하여 창의적으로 결합하는 것이다. 
근래의 변경상호 중에서 형태론울 잘 활용한 상호로는 과츠닉(Partnic)이 있는데 이는 대우 전자부품의 변경된 상호이다.

다음으로 변경상호 개발에서 우리나라와 목표 시장의 언어 현실을 고려하고 활용할 펼요 가 있다. 우리나라 소비자들은 한글, 한자어, 영어 둥에 대한 언어 지식을 보유하고 있다. 이를 반영하는 것으로 분석 결과, 우리나라 변경상호의 언어 대부분이 한자어, 영어 또는 이들이 결합된 복합어로 밝혀겼다. 그리고 변경상호로 영어 상호가 급증한 것으로 밝혀졌는 뎨 이는 전세계적으로 나타나고 있는 현상으로 소비자들의 영어 상호 선호 현상에 기인하는 것이다. 하지만 중국과 같은 언어권이 다른 지역에서는 현지 언어로 된 상호가 여전이 사용 되고 있다는 현실을 고려할 필요가 있다(Zhang and Schmitt 2001). 언어에서 보았을 때 바 람직한 변경상호 개발은 기업이 목표로 하는 시장의 사용 언어와 선호 언어률 고려하여 이 루어져야 할 것이다. 특히 목표 시장이 중국이나 한자사용권 지역인 경우에는 기존의 한자 어 상호를 군이 변경할 필요까지는 없을 것 같다. 다만 기존의 한자어 상호가 현지에서 연 상시키는 것에 대한 조사는 필요하며 이에 따른 의사졀정이 이루어지면 될 것이다.

\subsection{3 기존 상호률 완전히 다른 상호로 무조건 바꾸는 것은 좋지 않다.}

이 부분은 분석에서 다루지는 않았지만 상호변경 및 상호 브랜드에서 중요한 사항이므로 상호변경의 개별 사례에 기반하여 논의를 전개하였다. 우리나라의 변경된 상호의 특징 중에 하나는 이전에 사용했던 상호와 연결성이 낮다는 것이다. 오비맥주가 두산으로, 유원건설이 울트라건설로, 삼성출판사가 엔에스에프로 상호변경을 한 것이 이에 해당될 수 있는 사례이 다. 기존 상호와 단절된 상호를 사용하는 것이 바람직한 경우는 기존 상호의 이미지가 부정 적인 경우나 기업이 이전과 전혀 다른 사업으로 업종을 변경한 경우이다. 하지만 기업이 기 존 상호에 구축해 놓았던 브랜드 자산이 있는 경우에는 상호를 이전과 완전히 다른 상호로 변경하는 경우에는 이를 잃어 버릴 수 있다는 위험이 있다(Kohli and Hemnes 1995). 따라서 상호률 연결성이 약하거나 없는 상호로 변경하는 경우에는 기업 이해관계자들올 대상으로 한 기존 상호에 대한 조사가 필요하다.

사람이 대상에 대해서 받은 첫인상은 오래가고 잘 변하지 않는다는 특징이 있다(Schmitt and Simonson 1997). 상호는 기업 아이텐티티의 초석으로 기업 이해관계자들에계 기업에 대 한 첫인상을 형성해 준다(Schmitt and Pan 1994). 만약에 예전부터 사용해 왔던 상호에 대 해 기업 이해관계자들이 좋은 인상올 가지고 있고 그 상호가 상당한 브랜드 자산을 구축하 고 있고 기업이 해당 분야에 전문화된 기업이라면 굳이 완전히 다른 상호로 변경할 필요까 지는 없을 것이다. 상호의 기본 틀은 유지하면서 새로운 아이덴터터가 펄요하거나 기존 이 미지를 개선하고 싶다면 로고, 슬로건 등과 같은 다른 브랜드 구성 요소를 이용하거나 기존 의 상호를 단계적으로 변경시켜 나가는 방법을 대안으로 고려해 불 수 있다(Kohli, Suri, and Thakor 2002). 미국에서는 UAL 이 Allegis 라는 상호로 상호변경올 하였다가 강한 비난 을 받고 다시 UAL 로 복귀한 사례가 있다. 우리나라의 경우에는 전선과 케이블 전문 생산 기업으로 1960 년대에 설립된 대원전선이 1997 년에 엔케이전선(Enkay Wire \& Cable)으로 상 호를 변경하였다가 1999 년에 대원전선으로 복귀한 사례가 있다. 최근에 한빛은행이 상호를 우리은행으로 변경하면서 기존의 한빛은행 심볼을 활용하고 있는 것은 참고할 만한 좋은 사 례이다.

상호는 기업의 과거와 현재를 연결시켜 주는 고리이고 미래를 안내해주는 나침판 역할을 한다(Kohli and Hemnes 1995). 특히 기업이 영위하는 사업에서 소비자가 중시하는 요인이 
전통, 전문성이라면 다른 상호로 변경을 고려하는 기업은 신중해 질 펄요가 있다. 분석 결 과에서 나타난 한자어로의 상호변경 비율이 감소한 현상은 한번 생각해 불 펼요가 있다.

3.2.4 기업 비전, 사명, 미래 전략에 적절하고 구성원을 이끌어 줄 수 있는 것을 상호로 개발해야 하며 이러한 상호를 자주 바꾸는 것은 좋지 않다.

이 부분도 분석에서 다루지는 않았지만 상호에서 반드시 집고 넘어 가야할 사항이므로 개 별 사례와 기업 전략 및 아이덴티티 문헌에 기반하여 논의를 전개하였다. 기업의 브랜드 아 이덴티티는 크게 단일형과 분산형으로 나눌 수 있는데 분산형온 다각화된 소비재 기업에서 많이 나타나며 이들 기업은 다양한 개별 및 계열 브랜드률 사용하는 경향이 있다(Fombrun 1996). 단일 아이덴티티 기업의 경우에도 개별 브랜드 또는 계열 브랜드 전략을 사용하는 경향이 근래에 나타나고 있다(Keller 1998). 이런 경우에 상호와 제품 브랜드명이 다를 수 있다(Aaker and Joachimsthaler 2000). 이렬 때 기업의 상호와 다른 제품 브랜드명에 대한 관리는 다르게 이루어져야 한다(Keller 1998), 제품 브랜드명이 주로 상대하는 대상은 소비 자이며 이 경우에 브랜드 담당자의 주업무는 브랜드의 핵심 개념과 제품이 제공하는 편익을 소비자에게 마케팅하는 것이다. 하지만 기업의 상호에 관련되는 대상은 소비자, 투자자, 조 직 구성원, 경쟁자, 지역사희, 정부, 대중과 같이 광범위하다(Fombrun 1996). 이에 따라 상 호는 다양한 기업 이해관계자들의 기대와 욕구를 충족시켜 주는 역할을 해야 한다. 상호는 이 중에서 특히 조직 구성원인 직원둘에게 조직의 비전, 가치, 문화 둥올 전달해주는 상징 이며 구성원들의 조직에 대한 헌신(commitment)을 이끌어내는 중심체 역할을 해야 한다 (Margulies 1977, Olins 1989). 조직의 비전(핵심 이념, 미래 목표), 가치, 문화 등은 기업 의 상호보다 먼저 개발되고 정립되어져야 하는 것이다. 상호가 정해진 다음에 이러한 것들 이 정립될 수도 있지만 기업이 경쟁력있는 조직이 되려면 조직의 출범 이전에 기업의 비전, 가치, 문화에 대한 기본상이 구축되어 있어야 한다(Collins and Porras 1996).

줗은 비전은 조직과 조직 구성원을 이끌어주고 오랫동안 사용할 수 있으며 궙게 진부화되 지 않는다는 특징이 있다. 이런 경우에 상호는 이러한 기업 비전을 생생하게 표현하고 전달 해 주는 상징 수단이다. Nike 의 비전과 가치는 경쟁, 숭리, 경쟁자를 압도하는 경험을 제 공하는 것으로 요약할 수 있는데 이는 Nike 라는 상호로 잘 표현되어 있다. Nike 의 이전 상 호는 BRS(Blue Ribbon Sports)이었는데 1970 년대에 비전, 가치, 문화를 정립하고 상호를 Nike 로 변경한 후에 비로서 강한 조직이 되고 비약적인 성장을 할 수 있었다. 따라서 우리 나라 기업들도 상호를 변경하거나 신규 상호를 만들 때는 기업의 비전, 가치, 문화를 나타 내 줄 수 있는 것을 상호로 개발해야 한다. 그리고 이렇개 개발된 상호는 조직의 정체성이 담겨 있는 것이기 때문에 자주 변경해서는 안 된다. 하지만 분셕 결과 우리나라 기업의 상 호가 타당한 근거없이 야잔나 영어 상호로 변경되는 경우가 반대의 경우보다 높게 나타났으 며 개별 사례 분석에서도 자주 상호변경이 이루어졌다는 것을 발견할 수 있었다. 1987 년에 삼성출판사가 상호를 삼성이데아로 변경하였다가 1989 년에 원상호를 복귀한 후에 2000 년에 엔에스에프(NSF)로 변경한 사례가 있다. 또한 2000 년경에 닷컴(. com)으로 대표되는 인터 넷, 벤처 붐이 일자 상당수의 기업들이 . com, e, i 라는 영어 유행어를 상호에 추가했다가 최근에 이런 상호를 다시 변경하는 사례가 나타나고 있다. 이러한 상호 변경은 조직 구성원 들에게 자신들이 몸 담고 있는 기업의 정체성과 비전, 가치, 문화에 대하여 혼동을 일으키 게 하며 이들이 조직에 헌신하기 어렵게 만드는 요인으로 작용할 수 있다. 따라서 바람직한 상호는 기업의 정수를 담아낸 것으로서 최소한 10 년 이상을 사용할 수 있는 것이어야 하며 
시대와 환경의 변화에 견디어 낼 수 있는 것이어야 하고 일관성이 있어야 한다(Collins and Porras 1996)는 사실을 염두에 두고 담당자는 상호변경에 임해야 한다.

\section{3 연구의 시사점}

본 연구는 현재까지 연구되지 않았던 우리나라 상장기업 및 KOSDAQ 등록 기업의 상호변경 사례를 체계적으로 정리하고 그 내용을 분석하고 이률 바탕으로 바랍직한 상호 방안을 제시 한 탐색적인 논문이다. 이에 본 연구의 의의와 시사점은 다음과 같다.

첫째, 본 연구는 상호를 변경하거나 신규 상호를 개발하고자 하는 기업들에게 상호의 특 성과 역할을 제시하였다. 기업은 상호를 통해서 차별화할 수 있는데 차별화는 경쟁사와 소 비자 측면에서 주로 이루어진다. 본 연구에서 제시된 상호변경 톡성과 유형은 기업이 상호 률 이용하여 차별화하는 데 도움올 줄 수 있올 것이다. 논의에 제시한 긍정적인 소비자 반 웅을 일으키는 상호 특성들과 제시 사항들올 활용하면 기업의 상호 담당자는 상호변경 및 개발, 브랜드 관리의 효율성과 효과성을 높일 수 있을 것이다. 둘째, 상호변경에 대한 사례 분석을 통해 우리나라 기업의 상호변경 톡성에 대한 이해와 이를 기반으로 한 바람직한 상 호에 대한 제안을 통해 우리나라 기업의 상호변경에 대하여 재인식할 수 있는 기회률 제공 했다. 상호를 잘못 변경하면 기업에 부정적인 영향을 미칠 수도 있지만 본 연구에서 분석된 상호변경 사례들의 상당수는 변경된 상호로 인헤 기업의 마케팅 성과가 향상된 것으로 판단 된다. 특히 본 연구에서 제시한 상호변경에 성공한 기업의 상호 톡성에 대한 사례 분석올 통해 성공적인 상호의 특성에 대한 이해를 높일 수 있을 것이다. 마지막으로 상호와 제품 브랜드 비교를 통해 상호의 기능과 역할을 정립하고 이에 따른 시사점을 제시하였다. 상호 와 제품 브랜드가 다른 경우에는 상호 관리와 브랜드 관리는 다르게 이루어져야 한다 (Fombrun 1996). 하지만 우리나라 기업의 브랜드 담당자듈은 이률 같은 것으로 혼동하고 동 일하게 관리하는 경향이 있다. 이에 본 연구에서는 상호와 제품 브랜드의 차이점에 대하여 논하고, 상호 관리에 필요한 사항들에 대하여 제시하였다.

\section{4 연구의 한계 및 향후 연구 방향}

본 연구는 다음과 같은 한계를 지니고 있으므로 이에 대한 연구가 향후 연구에서 줗은 주 제가 될 수 있을 것이다. 첫째, 본 연구의 연구 방법은 상호변경 사례를 중심으로 한 내용 분석이다. 내용 분석의 타당성을 높이기 위해 사례 표본수를 706 개로 하여 업종별, 연대별 빈도와 비율 분석을 하였다. 하지만 내용 분석으로 변경 사례에 대한 심충 분석을 하지는 못하였다. 따라서 상호변경올 성공과 실패 사례로 나누어서 심충 내용 분석 연구를 실시한 다면 의미있는 결과를 얻을 수 있을 것이다. 둘째, 본 연구는 상호변경 효과를 브랜드 측면 에서 변경 전후의 상호 자체에 초점에 맞춰 분석하였다. 하지만 진정한 효과는 변경된 상호 에 대한 기업 이해관계자들의 반응에서 나오는 것이다. 따라서 기업 이해관계자들의 상호변 경 전후의 해당 기업 및 상호에 대한 반응 연구가 필요하다. 그리고 이를 시계열로 확장하 여 연구하면 더욱 의미있는 연구가 될 것이다. 셋째, 변경 상호에 대한 소비자 반웅에 영향 을 미치는 요소로는 상호 자체의 특성도 있지만 기업 특성, 상호변경에 따른 마케팅 활동, 소비자 특성, 경쟁사 반웅 등이 있을 수 있다. 따라서 향후에 이러한 변수들이 미치는 영향 을 고려한 연구가 필요하다. 마지막으로 기업의 상호변경은 상호만 변경하는 경우와 전체적 
인 CIP 에 의해 상호 브랜드 구성 요소의 상당수를 변경하는 경우 두가지가 있을 수 있다. 따라서 변경 범위에 따른 상호변경 효과롤 분석하거나 변경 내용을 사례로 하여 심층 분석 하는 것도 줗은 연구 주제가 될 수 있을 것이다. 


\section{<참고문헌>}

송영균 (1991), “상호변경이 주주의 부에 미치는 영향에 관한 연구," 중권학혀지, 13 , 67-101.

유창조, 김영찬 (2001), “기업상표와 개별상표의 이미지가 소비자의 차종선택에 미치는 영 향에 관한 연구: 정성적 조사와 정량적 조사의 통합적 접근," 마케팅연구, 16(4), 113136.

이태희, 박찬수 (2000), “ $\mathrm{CIP(Corporate} \mathrm{Identity} \mathrm{Program)에} \mathrm{의한} \mathrm{상호변경이} \mathrm{기업의} \mathrm{이}$ 읙흐름에 미치는 영향에 관한 연구," 한국마케팅저널, 2(4), 68-78.

조혁근 (2002), 브랜드 성공을 위한 상표관리, 서해문집.

Aaker, David A. (1991), "Managing Brand Equity: Capitalizing on the Value of a Brand Name," Free Press.

Aaker, David A. (1996), “ Building Strong Brands," Free Press.

Aaker, David A. and Erich Joachimsthaler (2000), "Brand Leadership: Building Assets in the Information Society," Free Press.

Businessweek (2001), "The 100 Top Brand," August 6, 50-64.

Collins, James C. and Jerry I. Porras (1996), "Building Your Company's Vision," Harvard Business Review, September-October, 65-77.

Fombrun, Charles J. (1996), "Reputation: Realizing Value from the Corporate Image," Harvard Business School Press.

Horsky, Dan and Patrick Swyngedouw (1987), “ Does It Pay To Change Your Company' s Name: A Stock Market Perspect ive," Marketing Science, 6(4), 320-335.

Interbrand (2000, 2001), "The World's Most Valuable Brand 2000, 2001. Interbradnd's Annual Survey," http://www.interbrand.com/league_chart.html.

Keller, Kevin Lane (1993), "Conceptualizing, Measuring, and Managing Customer-based Brand Equity," Journal of Market ing Research, 57(1), 1-22.

Keller, Kevin Lane (1998), "Strategic Brand Management: Building, Measuring and Managing Brand Equity," Prent ice-Hall.

Keller, Kevin L., Susan E. Heckler, and Michael J. Houston (1998), “ The Effects of Brand Name Suggestiveness on Advertising Recall," Journal of Marketing, 62(January), 48-57.

Klink, Richard R. (2000), "Creating Brand Names with Meaning: the Use of Sound Symbol ism," Marketing Letters, 11, 5-20.

Kohli, Chiranjeev and Thomas M. Hemnes (1995), "A Corporation By Any Other Name-*." ?". Business Horizons, November-December, 29-33.

Koku, Paul Sergius (1997), "Corporate Name Change Signaling in the Services Industry," Journal of Services Marketing, 11(6), 392-408.

Krishnan, Balaji C. and Michael D. Hartline (2001), "Brand Equity: Is It More Important in Services?" Journal of Services Marketing, 15(2), 328-342.

LeClerc, France, Bernd H. Schmitt, and Laurette Dube (1994),. "Foreign Branding and its Effect on Product Perceptions and Attitudes," Journal of Marketing Research, 
31(May), 263-270.

Margulies, Walter P. (1977), "Make the Most of Your Corporate Identity," Harvard Business Review, July-August, 66-74.

Murphy, John M. (1990), "Brand Strategy," Director Books.

01 ins, Wally (1989), "Corporate Identity," Harvard Business School Press.

Park, C. Whan, Bernard J. Jaworski, and Deborah J. MacInnis (1986), "Strategic Brand Concept-image Management," Journal of Marketing, 50(3), 135-145.

Ries, Al and Laura Ries (1998), "The 11 Immutable Laws of Branding," Harper Collins. Ries, Al and Jack Trout (1981), "Positioning: The Battle for Your Mind," McGraw-Hill Book Company.

Robertson, Kim (1989), "Strategically Desirable Brand Name Characteristics," Journal of Consumer Marketing, 6(4), 61-71.

Room, Adrian (1991), "NTC's Dictionary of Trade Name Origins," NTC Business Books. Schmitt, Bernd and Alex Simonson (1997), "Marketing Aesthetics," Free Press.

Zhang, Shi and Bernd H. Schmitt (2001), "Creating Local Brands in Multilingual International Markets," Journal of Marketing Research, 38(August), 313-325. 